\title{
Research Related to Breast Implant-associated Anaplastic Large Cell Lymphoma and its Influence on the Decision-Making Process Related to Reconstructive Techniques

\author{
Analysis of a series of cases and literature review
}

\begin{abstract}
SILVIU ADRIAN MARINESCU1', CATALIN GHEORGHE BEJ INARIU**, CARMEN GIUGLEA ${ }^{2}$
${ }^{1}$ Bagdasar-Arseni Emergency Clinical Hospital, Department of Plastic and Reconstructive Surgery, 12 Berceni Road, 041915, Bucharest, Romania

${ }^{2}$ Saint J ohn Emergency Clinical Hospital, Department of Plastic and Reconstructive Surgery, 13 Vitan-Barzesti Road, 042122, Bucharest, Romania

The worldwide increasing number of reports related to new cases of Breast Implant-associated Anaplastic Large Cell Lymphoma (BIA-ALCL) raises the interest of the scientific community in understanding the pathophysiology and the prognosis of these patients. This material presents the impact that BIA-ALCL exerts on the reconstructive options for patients who have undergone mastectomy. The research is based on data obtained from the analysis of a group of patients who have undergone 71 surgeries performed within the National Breast Reconstruction Program between 2015 and 2019. The statistical analysis revealed that $35.14 \%$ of the patients that were examined during the breast reconstruction consult refused the use of alloplastic techniques by invoking the potential associated risks described in the insufficient documentation of BIA-ALCL pathophysiology. Improving BIA-ALCL detection and reporting systems has led to an accelerated increase in the number of new diagnosed cases, determining the patients' reticence towards the use of alloplastic reconstructive techniques.
\end{abstract}

Keywords: BIA-ALCL, siliconic implant, breast reconstruction, lymphoma

Breast Implant-associated Anaplastic Large Cell Lymphoma (BIA-ALCL) is one of the most discussed topics in specialized literature dedicated to the use of breast implants, raising the interest of the international scientific community dedicated to understanding the impact of elective breastaugmentation and alloplastic reconstruction after mastectomy on the quality of life and the life expectancy of the patients. ALCL occupies the third position in the incidence of peripheral T-cell lymphoma, BIA-ALCL being introduced by the World Health Organization in 2016 in the classification of these diseases together with ALK () and $\operatorname{ALK}(+)$ systemic lymphoma, as well as the related form of skin cancer [1,2]. The immunohistochemical defining elements of this subtype of cancer are CD30 positivity, as well as the ALK (-) character [3], criteria that are part of the BIA-ALCL diagnostic protocol. The specificity of this relatively new type of neoplastic entity is caused by the association with the breast implant, and location in the immediate vicinity of it [4]. The history of this condition is relatively short, the first association between $A L C L$ and breast prosthesis being identified in 1997 in a 41-year-old patient who opted for breast augmentation for aesthetic purposes [5].

Silicon is the second most frequent element in the structure of the planet, representing $29.7 \%$ of the earth's crust by mass, being overtaken by oxygen with $46.6 \%$ and followed by of aluminum with $8.1 \%$. Concerning the human body the distribution changes, oxygen accounting for about $65 \%$ of the total mass, followed by carbon (18\%) and hydrogen (10\%). The total amount of silicon that exists in the human body varies between 5 and $10 \mathrm{~g}$. The principle of using silicone materials for medical purposes is based on observing the prolongation of the coagulation time in silicone coated glass containers [6]. The identification of this feature has underpinned the hypothesis that silicone is a stable material that interacts to a small extent with adjacent tissues.

Silicone breast implants have undergone multiple changes in the 59 years since the first use of this type of prosthesis. Subsequentstudies have led to the development of new techniques for treating silicone compounds in order to increase their consistency and resistance over time, as well as to improve their chemical stability. The coating of the prostheses are made up of three-dimensional silicone elastomers [7] with high mechanical strength that protects the silicone gel characterized by a variable cross-linking level and mechanical particularities strongly influenced by the degree of polymerization $[8,9]$. The consistency of the material increases in direct proportion to the number of dimethylsiloxane units within the polymers, affecting the physical properties of silicone [10]. The objective analysis of the psychological benefits related to elective augmentation and breast reconstruction with silicone implants should also consider the adverse effects associated with the chemical properties of these substances [11,12]. Therefore, the phenomenon of leakage, the variable stimulation of the immune system, and the possible post-traumatic disseminations are elements that require rigorous analysis when choosing the mammoplasty protocol [13].

The study of the predisposing risk factors suggests that biofilm related to the prosthetic material could be involved in the development of BIA-ALCL by stimulating a chronic inflammatory response. According to experts, there may be a potential involvement of lipopolysaccharides from the cell membrane of gram negative bacteria in triggering lymphocyte hyperplasia [14]. Also, the use of textured breast implants has a high degree of association with newly diagnosed cases. The specialized literature shows only isolated reports of patients diagnosed with BIA-ALCL

\footnotetext{
*email:drbejinariu@gmail.com
} 
associated with smooth-skinned breast prostheses, however it should be noted that they do not present the patients' complete history regarding possible changes of the prosthetic material. The association between textured implants and the onset of BIA-ALCL can be justified by the fact that unlike implants with a smooth coating, they exert a more powerful immune response with the marked involvement of both cytotoxic T cells and helper lymphocytes [15]. This hypothesis is supported by many specialists, showing that by detaching silicone microparticles from the textured coating, macrophages are subsequently stimulated and release cytokines (IL-1, IL-6) and tumor necrosis factor triggering T-type lymphocytes by chemotaxis, thus creating the premise of BIA-ALCL development [16]. Although the majority of the articles published in the specialized literature dedicated to understanding this condition support the association of BIA$A L C L$ with the use of textured implants, there are materials which show that this type of neoplasia is associated with a wide range of implants, while supporting the specific subtype specificities of this condition $[17,18]$.

\section{Experimental part}

Materials and Methods

The current research was conducted based on data analyzed between 2015 and 2019 within the National Program of Breast Reconstruction involving a batch of patients undergoing a number of 71 surgical interventions. The study compiles results related to the factors that influence the decision making process related to breast augmentation and reconstruction in the context of the worldwide increasing number of reported cases of BIAALCL.

The surgical consult involved counseling related to the available reconstructive options, including alloplastic and flap techniques, as well as the risk associated with each alternative including the possible long-term effects of siliconic materials.

The primary objective of the study was to determine the impact of BIA-ALCL during decision-making process regarding to the reconstructive surgical protocol. Another important goal was to present the current state of knowledge related to this rare form of lymphoma associated with breast implants in order to have an overview on the alternatives presented by the plastic surgeon during the examination.

The analysis of the specialized literature was based on research published in journals and magazines since 2015 using the Medline, PubMed, NCBI, Scopus and Research Gate platforms, as well as the Medscape database and the following main search terms: BIA-ALCL guidelines, breast reconstruction, implant structure, siliconic materials, capsular contracture pathogenesis.

The selected data was gathered from studies conducted by The American Society of Plastic Surgeon, The Association of Breast Surgery, The British Association of
Aesthetic Plastic Surgeons, The British Association of Plastic, Reconstructive and Aesthetic Surgeons, The National Comprehensive Cancer Network, US Food and DrugAdministration, World Health Organization and Patient Registry and Outcomes For breast Implants and anaplastic large cell Lymphoma etiology and Epidemiology (PROFILE).

\section{Results and discussions}

The statistical analysis of the data collected from the group of patients showed that $54.05 \%$ of the patients who came in for examination in order to discuss options related to breast reconstruction after mastectomy did not go through the surgical intervention (fig. 1).



- Breast reconstruction accepted

- Denial associated with other causes

Fig. 1 Patient ratio according to decisionmaking related to breast reconstruction

- Denial associated with BIA-ALCL

(mastectomy without complications)

\section{- Denial associated with BIA-ALCL}

(mastectomy with complications)

The main reason behind the negative response was represented by the increasing incidence of $B I A-A L C L, 65 \%$ of the patients that denied breast reconstruction have associated the risks related to the condition with the use of the expander-implant method, as well as the techniques involving the use of the silicone implant in combination with myocutaneous flaps. The insufficient documentation available in the international literature and the ascending trend in the number of reports were also important factors underlying the decision related to the surgical technique.

The average age of patients included in this subgroup was 52 years (fig. 2).

Regarding the rate of complications after mastectomy, results were above the average values presented in other materials published in the specialized magazines, 37.84\% of the patients presenting postoperative complications. The average time interval between mastectomy and the breast reconstruction consult including surgical examination was 1.8 years.


Fig. 2 Average patient age ratio in relation with decision-making related to breast reconstruction

- Breast reconstruction accepted Denial associated with BIA-ALCL Denial caused by other reasons 
Table 1

PATIENT RATIO AND TIME INTERVALS RELATED TO MASTECTOMY IN RELATION WITH THE PATIENTS' DECISION-MAKING REGARDING BREAST RECONSTRUCTION

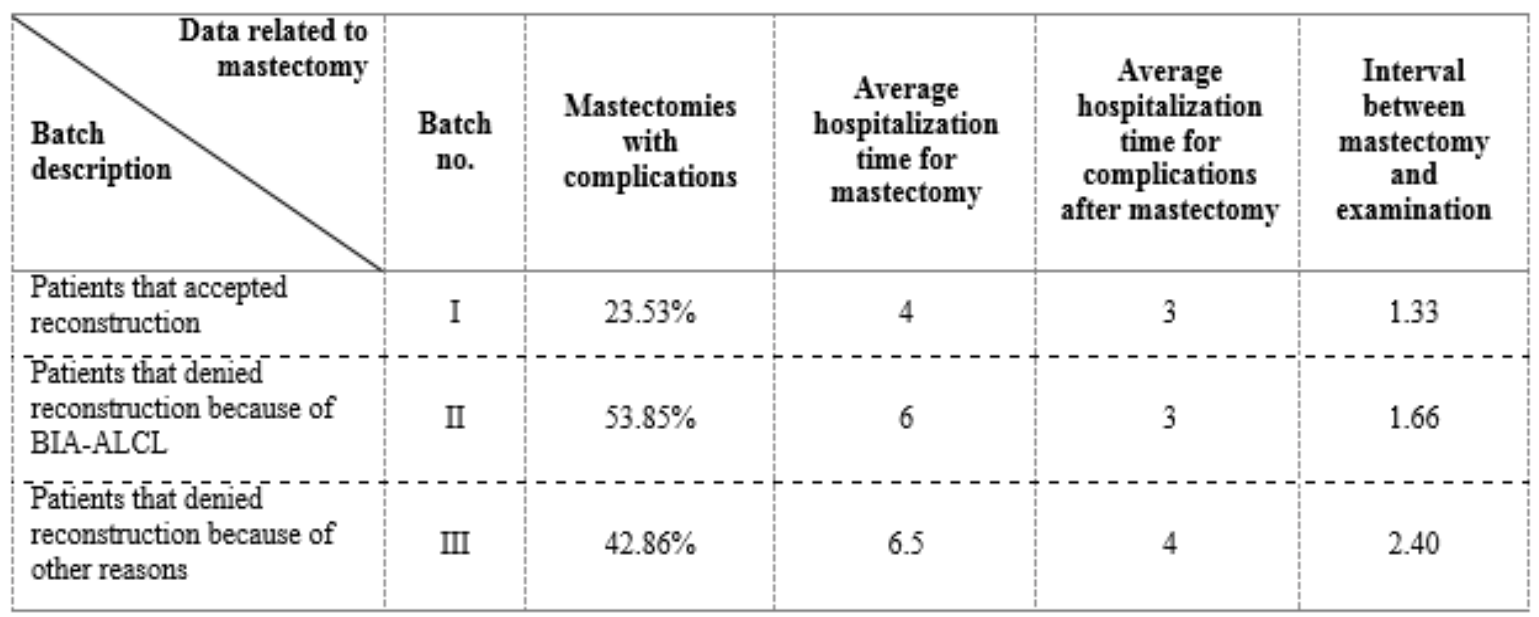

The group of patients was split in 3 batches in order to have an improved overview on the relevant statistical results (table 1).

\section{Batch 1-Patients that have accepted breastreconstruction}

Regarding patients that have accepted breast reconstruction, $23.53 \%$ have suffered complications after mastectomy. Less than half of the patients have accepted to go through breast reconstruction (45.95\%), $94.59 \%$ of them opting for the expander-implant technique, the transverse rectus abdominis myocutaneous (TRAM) flap technique being used for the rest of the patients. The average age in this group was 50.88 years and the average time elapsed since the mastectomy was 1.33 years. Patients in this batch have spent an average of 4 days in the hospital when the mastectomy was performed. Concerning the complication rate, $23.53 \%$ of the patients have suffered different forms of complications after mastectomy, an average of 3 hospitalization days being required in order to address these complications.

Batch II -Patients that have denied breast reconstruction because of the risks associated with BIA-ALCL

A considerable number of patients $(35.14 \%)$ have refused to perform breast reconstruction because of the increasing incidence of BIA-ALCL and the associated risks. The average age of the patients in this batch was 53.83 years and the average duration between the mastectomy and the surgical examination was 1.66 years. For the mastectomy an average of 6 hospitalization days was required, an extra 3 days being necessary in order to address the related complications. The high rate of complications (53.85\%) may also be a reason to justify the reticence of the patients that did not follow up after the consult.

\section{Batch III - Patients that have denied breast reconstruction because of other reasons}

Patients have denied breastreconstruction out of various other reasons, such as limited medical education, psychological trauma, limited financial resources, limited access to information related to the reconstructive techniques, factors related to culture and religion. The average age of these patients was 53 years and the average time span between the mastectomy and the consult was 2.4 years. Hospitalization time has had the highest values in case of these patients (average value $=6.5$ days). Within this batch, $42.86 \%$ of the patients have suffered complications after mastectomy, the patients spending 4 days in the hospital for the required additional treatment.
Identifying risk factors, determining the overall incidence and understanding the particularities related to the prognosis of BIA-ALCL are all elements that have yet to be elucidated and that trigger the necessity to develop relevant scientific projects and materials in order to facilitate the understanding of the pathophysiological mechanisms that lead to the appearance and the evolution of this condition.

Reports have indicated a number of 688 cases of BIAALCL worldwide from which 270 cases in the US, 17 cases leading to the death of patients [19]. Various international surveys have centralized data from 30 countries that have contributed to the development of an international reporting program in order to accelerate the process of understanding the pathophysiology and prognosis of this condition $[20,21]$. The risk of occurrence of BIA-ALCL shows a high degree of variability, with reporting limits of 1:3817, respectively 1:30000 implants. The factors that contribute to these discrepancies are represented by geographic location, type of implant, and reporting specificity. Regarding geographic variability, statistical analysis shows that Australia and New Zealand associate a risk ratio between 1:1000 and 1:10000 for textured implants [22], the Netherlands having a 1:6900 risk rate and Canadian reporting presenting a risk ratio of 1:24000 patients. In the United Kingdom the risk of occurrence is 1:28000 [23]. In the context of at least 10 million women who have benefited from breastaugmentation, the current rate being of approximately 1.5 million annual procedures according to USFDA reports, interpretation of the data is essential to understanding the effects of this condition on global level [24]. The shortcomings related to the incomplete medical history included in the reports are the central element in shaping this issue [25]. Reported to the total number of seromas occurring more than 1 year after the insertion of the textured implant with a ratio of $0.05-0.1 \%$ associated to this type of complication, only about $10 \%$ of the patients are diagnosed with BIA-ALCL $[26,27]$. The average age at which the disease is diagnosed is about 55 years old, affecting both patients undergoing breast augmentation and those included in post-mastectomy reconstructive programs $[28,29]$. Between $60 \%$ and $80 \%$ of the patients request surgical consultation due to a persistent seroma that determines breast asymmetry associated with pain, both breasts being affected in approximately $4.6 \%$ of the cases [30,31]. Regarding the time elapsed from mammography to diagnosis, the average duration is between 7 and 10 years, the limits being 2.2 months and 28 years, respectively [32]. 


\begin{tabular}{|c|c|c|c|}
\hline No. crt. & Diagnostic imagining & Specificity & Sensitivity \\
\hline $\begin{array}{c}1 \\
----\frac{--}{2} \\
-----\frac{-}{4}\end{array}$ & $\begin{array}{l}\text { Ultrasound } \\
\text { Computed tomography } \\
\text { Nuclear magnetic resonance } \\
\text { Positron emission tomography }\end{array}$ &  & 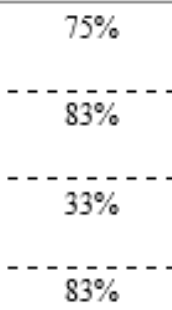 \\
\hline
\end{tabular}

Table 2

DIAGNOSTIC IMAGING CRITERIA RELATED TO SEROMAS [34]
Regarding the relation between BIA-ALCL and the adjacent structures, stage I lymphoma may be limited to the periprosthetic fluid and to the capsule, spreading beyond this structure in case IIA; in stage IIB a single lymph node is involved, while in stage III the invasion of the anatomical structures occurs, spreading beyond the affected mammary region and the related lymphatic system [33]. Metastasis may be detected in the liver, small intestine and bone structures in the advanced forms of this disease. Regarding paraclinical examinations related to seromas, specificity and sensitivity register different values depending on the diagnostic imaging investigations used (table 2).

The appearance of the capsular contracture is a multifactorial fibrotic process, the precise cause of which not being known till the present day [35]. Hypotheses underlying the triggering of the capsular formation process involve the presence of periprosthetic blood, bacterial microcontamination and the increased intensity of the immune response characteristic of foreign body reaction. One possible cause may be the exaggerated foreign body reaction, which determines the appearance of capsules and subsequently of the capsular contracture, the overall incidence being $10.6 \%$. The textured implants may be associated with a lower rate of this complication compared to those with a smooth surface [36]. The presence of the periprosthetic capsule has raised the interest of the international community, especially in identifying solutions that could inhibit its development process. In case of wild mice periostin inhibition is associated with a decrease in the thickness of the periprosthetic capsule, low values being registered related to markers specific to CTGF and alpha - SMA fibrotic tissue formation [37]. Regarding the histological characteristics of the implant capsule, there is a significant difference in thickness betw een the capsules harvested from patients with stage I according to Baker classification compared to more advanced stages. Also, capsular contracture can lead to a high degree of alignment related to collagen fibers, as well as a positive alpha-SMA [38].

BIA-ALCL diagnosis starts with the appearance of the first clinical manifestations represented by increased breast volume and is supported by the ultrasound of the mammary, axillary, parasternal and supraclavicular regions. Finally, BIA-ALCL is confirmed by the positivity of CD30 protein associated with ALK- $[39,40]$. Histological confirmation during cytological examination is based on the identification of large anaplastic cells, as well as the multiplication of T-cell clones [41]. In regard to the diagnosis of the tumor masses, the international consensus is to perform the biopsy puncture with the identification of the parameters presented above, with the possibility of associating them with other immunohistochemical markers such as CD2, CD4, CD43 and CD45 [42]. The identification of possible metastases requires imaging investigations that can provide additional data during the initial stages of the diagnosis, such as magnetic resonance imaging and positron emission tomography $[43,44]$.

BIA-ALCL treatment primarily involves the extraction of the implant, followed by the excision of the affected capsule and the possible associated tumor masses. There is no solid foundation for mastectomy since lymphoma is not a neoplastic process of the mammary gland, therefore, in the absence of the invasion of the glandular tissue, radical mastectomy is not justified [45]. The complete excision of the capsular invasion is mandatory for localized forms after diagnosing the condition using puncture aspiration which must contain at least $10 \mathrm{~mL}$ of serum. The reconstructive options are delayed or immediate reconstruction depending on the stage of the condition, the use of textured prostheses not being indicated [46,47]. In terms of life expectancy after treatment, the invasion of the lymph nodes is associated with a $75 \%$ survival rate of, compared with $97.9 \%$ for patients with BIA-ALCL located only at the capsule level [48]. Encouraging results are related to the treatment of localized forms, advanced forms having a reduced incidence; life expectancy related to this type of neoplasm may exceed $90 \% 10$ years after treatment $[49,50]$.

Regarding patient monitoring in cases of elective breast augmentation or reconstruction after mastectomy, no additional investigations are required for asymptotic patients, the presence of seroma occurring more than 12 months after mammoplasty being the element that has to trigger the diagnostic procedures in order to identify a potential BIA-ALCL [51].

\section{Conclusions}

The increased number of reports regarding new cases of BIA-ALCL was a limiting factor in the inclusion of patients in the reconstructive algorithm after mastectomy. Specialized literature shows that this condition is characterized by a low incidence with a favorable prognosis in the early identified forms, however the patients' reticence seems to be based on the lack of rigorous scientific documentation determined by the recent identification of BIA-ALCL, as well as the faulty reporting system.

It is imperative to follow international guidelines that present all associated risks related to breast reconstruction using silicone implants given the high rate of patients who have given up on alloplastic reconstruction invoking the potential associated risks.

Improving knowledge of the pathophysiology related to this disease can be the solution for regaining the patients' trust. Moreover, complete and accurate information should be the basis for the patients' decision-making process related to breast reconstruction using alloplastic methods and the associated risks that they have to take.

Given the dimensions of the batches within the group of patients and the fact that the study included only alloplastic breast reconstruction without addressing the issue of 
elective augmentation, additional trials based on larger groups and extensive procedural coverage are needed in order to facilitate the understanding of the impact that BIA$\mathrm{ALCL}$ exerts on the patients' choices related to the reconstructive protocol.

\section{References}

1.SWERDLOW, S.H., CAMPO, E., HARRIS, N.L., JAFFE, E.S., PILERI, S.A., STEIN, H., THIELE, J., WHO Classification of Tumours, 4, nr. 2, 2017.

2.IBRAHIM, A.E., ATIYEH, B.S., SARHANE, K.A., CLEMENS, M., Breast Reconstruction, 2016, p. 1491.

3.SWERDLOW, S.H., CAMPO, E., PILERI, S.A., HARRIS, N.L., STEIN, H., SIEBERT, R., ADVANI, R., GHIELMINI, M., SALLES, G.A., ZELENETZ, A.D., JAFFE, E.S., Blood, 127, nr. 20, 2016, p. 2375.

4.DE LEVAL, L., MILOWICH, D., Springer, Cham, 2018, p. 1.

5.KEECH, J .A. Jr., CREECH, B.J., Plast Reconstr Surg, 100, nr. 2, 1997, p. 554.

6.KAPPEL, R.M., KLUNDER, A.J.H., PRUIJN, G.J.M., Eur J Plast Surg, 37, 2014, p. 123.

7.SLATINEANU, L., DODUN, O., NAGIT, G., COTEATA, M., BOSOANCA,

G., BESLIU, I., Mat. Plast., 55, no. 4, 2018, p. 474.

8.YANG, N., MURADALI, D., AJR, 196, 2011, p. 451.

9.MAXWELL, G.P., GABRIEL, A., Clin Plastic Surg, 36, 2009, p. 1.

10.NISTOR, A., PUSZTAI, A.M., SORA, M.C., HOINOIU, B., IONAC, M., MATUSZ, P., Mat. Plast., 54, no. 3, 2017, p. 578.

11.BEJINARIU, C.G., MARINESCU, S.A., ENESCU, M.D., Modern Medicine, 26(1), 2019, p. 17.

12.FILIP, C.I., BERBECE, S., RADUCU, L., FLORESCU, I.P., ARDELEANU, V., JECAN, C.R., Mat. Plat., 54, no. 3, 2017, p. 414.

13.CHICEA, R., CHICEA, A.L., MIHETIU, A., TANTAR, C.A., CERNUSCA MITARIU, M.M., CERNUSCA MITARIU, S.I., ROMAN, C., COMANEANU, R.M., BRATU, D., MANEA, M.M., Mat. Plast., 55, no. 1, 2018, p. 99.

14.HU, H., JOHANI, K., ALMATROUDI, A., VICKERY, K., VAN NATTA, B., KADIN, M.E., BRODY, G., CLEMENS, M.W., CHEAH, C.Y., LADE, S., JOSHI, P.A., PRINCE, H.M., DEVA, A.K., Plast Reconstr Surg, 137, nr. 6 , 2016, p. 1659.

15.BARR, S.P., HILL, E.W., BAYAT, A. Aesthet Surg J, 38, nr. 9, 2018, p. 962.

16.WOLFRAM D, RABENSTEINER E, GRUNDTMAN C, BOCK, G., MAYERL, C., PARSON, W., ALMANZAR, G., HASENÖHRL, C., PIZAKATZER, H., WICK, G., Plast Reconstr Surg, 129, nr. 2, 2012, p. 327.

17.LOCH-WILKINSON, A., BEATH, K.J., KNIGHT, R.J.W., WESSELS, W.L.F., MAGNUSSON, M., PAPADOPOULOS, T., CONNELL, T., LOFTS, J., LOCKE, M., HOPPER, I., COOTER, R., VICKERY, K., JOSHI, P.A., PRINCE, H.M., DEVA, A.K., Plast Reconstr Surg, 140, nr. 4, 2017, p. 645. 18.OISHI, N., BRODY, G.S., KETTERLING, R.P., VISWANATHA, D.S., HE, R., DASARI, S., MAI, M., BENSON, H.K., SATTLER, C.A., BODDICKER, R.L., MCPHAIL, E.D., BENNANI, N.N., HARLESS, C.A., SINGH, K., CLEMENS, M.W., MEDEIROS, L.J., MIRANDA, R.N., \& FELDMAN, A.L., Blood, 132, nr. 5, 2018, p. 544.

19.*** AMERICAN SOCIETY OF PLASTIC SURGEONS, Journal of the American Society of Plastic Surgeons, 143, nr. 2, 2019.

20.DOREN, E.L., MIRANDA, R.N., SELBER, J.C., GARVEY, P.B., LIU, J., MEDEIROS, L.J ., BUTLER, C.E., CLEMENS, M.W., Plast Reconstr Surg, 139, nr. 5, p. 1042.

21.CLEMENS, M.W. Plast Reconstr Surg, 140, nr. 4, 2017, p. 660.

22.DE BOER, M., VAN LEEUWEN, F.E., HAUPTMANN, M., OVERBEEK, L.I.H., DE BOER, J.P., HIJ MERING, N.J., SERNEE, A., KLAZEN, C.A.H., LOBBES, M.B.I., VAN DER HULST, R.R.W.J ., RAKHORST, H.A., DE JONG, D. JAMA Oncol. 4, nr. 3, 2018, p. 335.

23.BAAPS, ABS and BAPRAS, Medicines \& Healthcare products Regulatory Agency, 2018, p. 1.

24.US FOOD AND DRUG ADMINISTRATION. U.S. Department of Health and Human Services, 2019.

25.ZAKHARY, J.M., HAMIDIAN JAHROMI, A., CHAUDHERY, S., KIM, M., J La State Med Soc, 165, nr. 1, 2013, p. 26.
26.MCGUIRE, P., REISMAN, N.R., MURPHY, D.K., Plast Reconstr Surg, 139, nr. 1, 2017, p. 1.

27.DI NAPOLI, A., PEPE, G., GIARNIERI, E., CIPPITELLI, C., BONIFACINO, A., MATTEI, M., MARTELLI, M., FALASCA, C., COX, M.C., SANTINO, I., GIOVAGNOLI, M.R., PLoS One, 12, nr. 7, 2017.

28.CLEMENS, M.W., MEDEIROS, L.J., BUTLER, C.E., HUNT, K.K., FANALE, M.A., HORWITZ, S., WEISENBURGER, D.D., LIU, J., MORGAN, E.A., KANAGAL-SHAMANNA, R., PARKASH, V., NING, J , SOHANI, A.R., FERRY, J.A., MEHTA-SHAH, N., DOGAN, A., LIU, H., THORMANN, N., DI NAPOLI, A., LADE, S., PICCOLINI, J., REYES, R., WILLIAMS, T., MCCARTHY, C.M., HANSON, S.E., NASTOUPIL, L.J ., GAUR, R., OKI, Y., YOUNG, K.H., MIRANDA, R.N., J Clin Oncol, 34, nr. 2, 2016, p. 160. 29.LAURENT, C., DELAS, A., GAULARD, P., HAIOUN, C., MOREAU, A., XERRI, L., TRAVERSE-GLEHEN, A., ROUSSET, T., QUINTIN-ROUE, I., PETRELLA, T., EMILE, J.F., AMARA, N., ROCHAIX, P., CHENARD-NEU, M.P., TASEI, A.M., MENET, E., CHOMARAT, H., COSTES, V., ANDRACMEYER, L., MICHIELS, J.F., CHASSAGNE-CLEMENT, C., DE LEVAL, L., BROUSSET, P., DELSOL, G., LAMANT, L., Ann Oncol 27, nr. 2, 2016, p. 306.

30.BAUTISTA-QUACH, M.A., NADEMANEE, A., WEISENBURGER, D.D., CHEN, W., KIM, Y.S., Clin Breast Cancer, 13, nr. 6, 2013, p. 492.

31.SUCIU, B.A., HALMACIU, I., BUD, V., COPOTOIU, C., FODOR, D., TRAMBITAS, C., GODJ A, D., VUNVULEA, V., MOLNAR, C., BRINZANIUC, K.Mat. Plast., 54, no. 4, 2017, p. 626.

32.BRODY, G.S., DEAPEN, D., TAYLOR, C.R., PINTER-BROWN, L., HOUSE-LIGHTNER, S.R., ANDERSEN, J.S., CARLSON, G., LECHNER, M.G., EPSTEIN, A.L., Plast Reconstr Surg, 135, nr. 3, 2015, p. 695.

33.PRO, B., ADVANI, R., BRICE, P., BARTLETT, N.L., ROSENBLATT, J.D., ILLIDGE, T., MATOUS, J., RAMCHANDREN, R., FANALE, M., CONNORS, J.M., YANG, Y., SIEVERS, E.L., KENNEDY, D.A., SHUSTOV, A., J Clin Oncol, 30, nr. 18, 2012, p. 2190.

34.ADRADA, B.E., MIRANDA, R.N., RAUCH, G.M., ARRIBAS, E., KANAGAL-SHAMANNA, R., CLEMENS, M.W., FANALE, M., HAIDERI, N., MUSTAFA, E., LARRINAGA, J., REISMAN, N.R., JASO, J., YOU, M.J ., YOUNG, K.H., MEDEIROS, L.J., YANG, W., Breast Cancer Res Treat, 147, nr. 1, 2014, p. 1.

35.BEJ INARIU, C.G., MARINESCU, S., GIUGLEA C., Romanian Medical Journal, LXVI(1), 2019, p. 33.

36.HEADON, H., KASEM, A., MOKBEL, K., Arch Plast Surg. 42, nr. 5, 2015, p. 532.

37.BAE, H.S., SON, H.Y., LEE, J.P., CHANG, H., PARK, J.U., BioMed Research International, 2018.

38.BUI, J.M., PERRY, T.A., REN, C.D., NOFREY, B., TEITELBAUM, S., VAN EPPS, D.E., Aesthetic Plast Surg, 39, nr. 3, 2015, p. 306.

39.STORY, S.K., SCHOWALTER, M.K., GESKIN, L.J ., 2013. Oncologist, 18, nr. 3, 2013, p. 301.

40.FERRERI, A.J ., GOVI, S., PILERI, S.A., SAVAGE, K.J ., Crit Rev Oncol Hematol, 85, nr. 2, 2013, p. 206.

41.DI NAPOLI, A., JAIN, P., DURANTI, E., MARGOLSKEE, E., ARANCIO, W., FACCHETTI, F., ALOBEID, B., SANTANELLI DI POMPEO, F., MANSUKHANI, M., BHAGAT, G., Br J Haematol, 180, nr. 5, 2018, p. 741. 42.RUPANI, A., FRAME, J. D., KAMEL, D., Aesthetic Surgery J ournal, 35, nr. 5, 2015, p. 533.

43.J OHNSON, L., O'DONOGHUE, J.M., MCLEAN, N., TURTON, P., KHAN, A.A., TURNER, S.D., LENNARD, A., COLLIS, N., BUTTERW ORTH, M., GUI, G., BRISTOL, J., HURREN, J., SMITH, S., GROVER, K., SPYROU, G., KRUPA, K., AZMY, I.A., YOUNG, I.E., STAIANO, J.J ., KHALIL, $H_{\text {., }}$ MACNEILL, F.A., Eu J Surg Oncol, 43, 2017, p. 1393.

44.ALDERUCCIO, J.P., DESAI, A., YEPES, M.M., CHAPMAN, J.R., VEGA, F., LOSSOS, I.S., Clin Case Rep, 6, nr. 4, 2018, p. 634.

45.CHESON, B.D., FISHER, R.I., BARRINGTON, S.F., CAVALLI, F., SCHWARTZ, L.H., ZUCCA, E., LISTER, A., J Clin Oncol, 32, nr. 27, 2014, p. 3059.

46.MEHTA-SHAH, N., CLEMENS, M.W., HORWITZ, S.M., Blood J ournal, 132, nr. 18, 2018, p. 1889.

47.BEJ INARIU, C.G., APOSTOLESCU, I., MARINESCU, S., Romanian J ournal of Medical Practice, 14 (1), 2019, p. 48. 
48.FERRUFINO-SCHMIDT, M.C., MEDEIROS, L.J., LIU, H., CLEMENS, M.W., HUNT, K.K., LAURENT, C., LOFTS, J., AMIN, M.B., MING CHAI, S., MORINE, A., DI NAPOLI, A., DOGAN, A., PARKASH, V., BHAGAT, G., TRITZ, D., QUESADA, A.E., PINA-OVIEDO, S., HU, Q., GARCIA-GOMEZ, F.J., JOSE BORRERO, J., HORNA, P., THAKRAL, B., NARBAITZ, M., HUGHES, R.C. 3RD, YANG, L.J., FROMM, J.R., WU, D., ZHANG, D., SOHANI, A.R., HUNT, J., VADLAMANI, I.U., MORGAN, E.A., FERRY, J.A., SZIGETI, R., TARDIO, J.C., GRANADOS, R., DERTINGER, S., OFFNER, F.A., PIRCHER, A., HOSRY, J., YOUNG, K.H., MIRANDA, R.N., Am J Surg Pathol, 42, nr. 3, 2018, p. 293.
49.DE SILVA, I.M., TEAGUE, J .A., BLAKE, W.E., J Plast Reconstr Aesthet Surg, 66, nr. 12, 2013, p. 1773.

50.LETOURNEAU, A., MAEREVOET, M., MILOWICH, D., DEWIND, R., BISIG, B., MISSIAGLIA, E., DE LEVAL, L., Virchows Arch, 473, nr. 4, 2018, p. 505.

51.CLEMENS, M.W., HORWITZ, S.M., Aesthet Surg J, 37, nr. 3, 2017, p. 285.

Manuscript received: 9.12.2018 